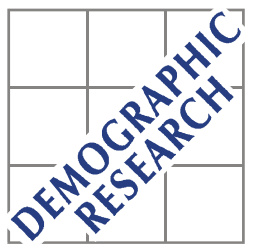

Demographic Research a free, expedited, online journal of peer-reviewed research and commentary in the population sciences published by the Max Planck Institute for Demographic Research Doberaner Strasse 114 D D-18057 Rostock · GERMANY www.demographic-research.org

DEMOGRAPHIC RESEARCH

VOLUME 7, ARTICLE 17, PAGES 565-592

PUBLISHED 11 DECEMBER 2002

www.demographic-research.org/Volumes/Vol7/17/

DOI: 10.4054/DemRes.2002.7.17

Research Article

\title{
A comparative analysis of leaving home in the United States, the Netherlands and West Germany
}

Clara H. Mulder

William A.V. Clark

Michael Wagner

(C) 2002 Max-Planck-Gesellschaft. 


\section{Table of Contents}

1 Introduction $\quad 566$

2 The context of leaving home: differences between 567 the United States, The Netherlands and West

Germany

2.1 Demographic change in the United States, the 567

Netherlands and West Germany

2.2 Three different housing markets 568

2.3 Three different welfare regimes 570

$\begin{array}{lll}2.4 & \text { Three different geographies } & 571\end{array}$

$2.5 \quad$ Spatial and temporal within-country contexts 571

2.6 Hypotheses on differences between the countries 572

$3 \quad$ Individual and parental resources $\quad 572$

$4 \quad$ Data, methods and variables $\quad 573$

4.1 Data 573

4.2 Methods $\quad 575$

$\begin{array}{lll}4.3 & \text { Independent variables } & 575\end{array}$

$5 \quad$ Analysis, models and results 578

$5.1 \quad$ Leaving home and the respondent's own resources 578

5.2 Leaving home and the parents' resources 584

5.3 Leaving home and the spatial-temporal context 585

$6 \quad$ Conclusions and findings $\quad 586$

$7 \quad$ Acknowledgements $\quad 588$

$\begin{array}{ll}\text { Notes } & 589\end{array}$

$\begin{array}{ll}\text { References } & 590\end{array}$ 
Research Article

\title{
A comparative analysis of leaving home in the United States, the Netherlands and West Germany
}

\author{
Clara H. Mulder 1 \\ William A.V. Clark ${ }^{2}$ \\ Michael Wagner ${ }^{3}$
}

\begin{abstract}
We investigate how leaving the parental home differs between three countries with different welfare-state and housing systems: the USA, the Netherlands and West Germany. Using longitudinal survey data, we examine the transitions of leaving home to live with and without a partner. We find that, much more than in the European countries, union formation has become separated from leaving home in the USA. We also find a different impact of level of education and employment status on leavinghome patterns in the European countries with their social-welfare state system than in the US system in which market forces prevail. The differences are not just related to welfare-state systems but also to the sizes of the countries and the geographical dispersion of jobs and educational opportunities.
\end{abstract}

University of Amsterdam, E-mail: C.Mulder@frw.uva.nl

University of California, Los Angeles, E-mail: wclark@geog.ucla.edu

Cologne University, E-mail: mwagner@wiso.uni-koeln.de 


\section{Introduction}

There is general agreement that the early adult years are marked by substantial changes as young people make the difficult transition from childhood to adult roles. In the United States and Western Europe, the period between ages 18 and 25 is a period of completing schooling, establishing occupations and creating new households. It is during this transition stage that the young persons become less dependent on their parents and their well being becomes a function of their own labor force participation and resources.

The process of leaving the parental home and the changes through historical time in this process are remarkably different between the various industrialized countries (Cherlin, Scabini \& Rossi 1997; Fernandez Cordón 1997; Billari et al. 2001). One of the most marked differences between the countries is the role of living without a partner in leaving home. Delays in first union formation are more or less universal, but the extent to which living alone or with roommates is an option for young adults is much greater in Northern European and North American countries than in Southern Europe. Between-country comparisons, therefore, are especially instructive for understanding the process of leaving the parental home.

In this paper we examine the transition to independent living in three different social and economic contexts: the United States, the Netherlands and West Germany (Note 1). Our research question is: To what extent can the timing of the events of leaving the parental home to live with and without a partner be explained by young adults' and their parents' resources and by rural-urban differences, and how does the influence of these factors differ between the United States, the Netherlands and West Germany?

Although the three countries are similar in some ways, there are also important contrasts between them, and it will be possible to evaluate the impact of different social economic contexts on the nature of leaving home. The Netherlands and West Germany are both social-welfare states, and they have different housing markets with varying degrees of social support for new households. The United States has only limited social support, and, outside of New York, almost no housing support. The market can be seen as a more controlling force in the United States.

Data from the Panel Study of Income Dynamics for the United States, from two retrospective surveys for the Netherlands and from the German Life History Study allow us to develop relatively standardized models of leaving home. The models explain the differing trajectories into residential independence as a function of variables that capture the impact of education, young adult and parental resources, in addition to controls for age, gender, and changes through time. Furthermore, an important feature 
of our models is the inclusion of degree of urbanization, an indicator for the housing market and spatial context.

\section{The context of leaving home: differences between the United States, The Netherlands and West Germany}

\subsection{Demographic change in the United States, the Netherlands and West Germany}

Since World War II, there has been a decrease in the age at which young people leave the parental home in the three countries. But in the 1980s and 1990s, this process reversed and has been replaced by a slight postponement in the age of leaving. In the United States, 51.6 percent of males aged 20-24 lived at home in 1994 compared with 49.5 percent in 1986. Among US women, this percentage grew from 36.3 percent to 37.3 percent in the same period (Goldscheider 1997). In West Germany and the Netherlands the percentages living at home were greater (around 65 percent for males aged 20-24 and around 43 percent for females), but hardly changed between 1986 and 1994 (Hooimeijer \& Mulder 1998).

Living with other young adults of the same or different sexes was a totally new phenomenon in the 1960s and 1970s. Prior to 1960, most young adults in the United States lived at home with their parents until marriage. Changing cultural attitudes made changes in this pattern much more acceptable to society as a whole. But, as we noted above, later cohorts have not been in as much of a hurry to leave home, and there has been a stretching out of the process of leaving the parental home. Clearly, the slowdown in independent living is a complex process. But, for the United States, the evidence points to an interconnection amongst the rising cost of housing, the costs of higher education and the loans that many young adults have assumed to complete their education. It cannot be ruled out, however, that a rising standard of living inside the parental home has also played a role. Overall, the trends suggest that more young people are living with their parents, more are living alone or with a cohabiting partner, and fewer are maintaining married couple or family households of their own (Bouvier $\&$ De Vita 1991). Consequently, the patterns are more diverse than in previous decades.

The changes in the transition to adulthood are closely connected with changes in the age at marriage for both men and women. In the United States, the delay in marriage has added about three years to the transition to adulthood in the period between 1960 and 1990. Early marriage was associated with a general tendency to live away from home in the 1960s and 1970s. As the baby boom generation came of age, and contraception improved, many young people lived away from home in non-marital situations. Cohabitation increased, but also the proportion of adults living on their own 
or with unrelated adults was substantially higher in 1990 than in 1970 (McClanahan and Casper 1995).

In the Netherlands, the age at marriage was at its lowest in 1975 (just under 23 for women, and around 25 for men), and by 1999 it had increased by five years. Whereas in the early 1970s fewer than one in five women who married in their twenties had cohabited before marriage, almost 90 percent had done so in 1995-1997 (De Jong \& Van Hoorn 1999). In West Germany, the age at first marriage in 1950 was 28.1 for men and 25.4 for women. In 1970, people married earlier with a mean age of 25.6 for men and 23.0 for women. In 1999, however, age at first marriage was not only high again but higher than in the 1950s: 31.1 for men and 28.4 for women. Also in West Germany cohabitation became more and more prevalent, especially among younger people. In 1995, 10.6 percent of all men and women between the ages of 25 and 34 lived in cohabitating unions (Engstler 1997).

All in all, it is probably justified to state that the three countries are in similar stages of individualization of demographic behavior, termed the Second Demographic Transition by Van de Kaa (1987). In accordance with this Second Demographic Transition, the process of leaving the parental home has been subject to a denormisation, permitting young people longer periods of living as a single person (Billari et al. 2001).

The social and demographic changes are being paralleled by important economic changes, which also impact the likelihood of young adults being able to create and sustain independence. Children who are becoming young adults in the $21^{\text {st }}$ century are making that transition in a different economic climate than three decades ago, when the baby boomers first began the transition to young adulthood. Wages, especially for lesser skilled jobs, have declined relatively in the United States, and the increase in marital instability and the rise in single parent families has made it more difficult for parents to help their young children in the passage to adulthood. Now it is economically critical that young adults gain college educations, and those who do not are likely to be disadvantaged in the labor market. This role of college and the acquisition of human capital is more critical in today's globalized world than it may have been for baby boomers who entered young adulthood in the 1950s and 1960s. Later in this presentation we will focus on the role of resources in the ability of young adults to achieve independence.

\subsection{Three different housing markets}

The rate of household formation, either the creation of single person or married households, is inextricably bound up with the operation of the housing market. Lower 
cost or subsidized housing may facilitate the creation of new households, or conversely, higher cost or restrictions on the supply of housing may impede household formation. In the United States, housing has increased in cost in the past two decades, especially in the large urban centers. There are almost no subsidies in the US housing market apart from the tax advantages of home-ownership (Note 2). Age adjusted home-ownership rates of married couples have declined in the past two decades, a decline which is most notable amongst young married households (Haurin, Hendershott \& Wachter 1996). Real house prices have increased sharply in the East and West coast of the United States in the past decade, while the rest of the US has not experienced such sharp increases. For young adults in these regions, these price changes are a further constraint on union formation and market penetration.

The Netherlands housing market has a history of strong government control and a substantial and high-quality social sector - just over one third of the housing stock was in the social rented sector in 1999. In the postwar decades, the control by national and local governments included construction programs, rent control, subsidies (both individual rent subsidies and brick and mortar subsidies) and allocation rules. From the 1970s, it was an explicit government aim to provide housing for young singles and young couples, and construction programs were started to cater for this category. Since the mid 1980s, the government intervention in construction decreased and stronger rent increases were allowed, leading to an improved competitiveness of the owner-occupied sector and a growth in the share of owner-occupied housing. The price of owneroccupied housing also increased, but only in the second half of the 1990s did it reach a level that made it increasingly difficult for young people to buy a home early in life. Special features of the Dutch market for owner-occupied housing are the low amount of down payment asked by mortgage banks and the generous tax treatment of homeowners.

The West German housing market resembles the Dutch housing market more than it does the US market. However, it differs from the Dutch in, among other things, the lower government expenditure on housing subsidies; the higher price of owneroccupied housing; and the much greater importance of the private rental sector. The share of owner-occupied housing has long been larger than in the Netherlands, but in the 1970s the Netherlands surpassed West Germany in this respect. In West Germany, mortgage banks have remained more conservative in asking down payments than in the Netherlands. Moreover, the tax treatment of owners is less generous, whereas savings anticipating home-ownership are promoted by means of the Bausparen scheme. All in all, the conditions for home-ownership are such that the importance of assets is greater in West Germany, whereas that of current income is greater in the Netherlands (Mulder \& Wagner 1998). 


\subsection{Three different welfare regimes}

Not only are the housing markets different, the three countries also have different welfare state systems, or welfare regimes as Esping-Andersen (1999) denotes them. In Esping-Andersen's classification, the United States is a Liberal Market welfare regime. The Netherlands and West Germany are Conservative Continental European welfare regimes, although the Netherlands is closer to a Social-Democratic regime than West Germany. In general, one can expect employment status and income to be more pertinent to leaving home in liberal welfare regimes as the United States than in conservative welfare regimes as the Netherlands and West Germany (Aassve et al. 2001).

In accordance with the welfare regimes, the social support systems are indeed variable across the three contexts we are examining in this paper. While the Netherlands and Germany have some similarities in their social support systems, there are strong contrasts with the very low levels of support in the United States.

Only a small fraction of American households receives public assistance, and the number has decreased after the welfare reform efforts of 1996. Now about 2-10 percent of the native born population receives some assistance, the proportion varies according to state and by ethnic status. Assistance comes as general assistance to individuals and households meeting a minimum income standard, aid to families with children and medical and food stamp assistance. Other targeted programs reach very small numbers of the total population. Black households are more likely to be receiving what is now called Temporary Assistance to Needy Families (TANF) and what was previously know as AFDC, or aid to families with dependent children. Average public assistance support was about 8 percent for native-born households and about 2 percent higher for the foreign born population. Some foreign-born groups had significantly higher levels of support. Recent immigrants from The Dominican Republic and refugees from South East Asia were much more likely to receive support, nearly 35 percent and 18 percent respectively (Clark 2001). The various forms of public assistance have in common that they provide some households with a minimal safety net, but not really an income a young home-leaver could live on without support from the parental family. There is virtually no housing support, though local agencies provide rental payment support at very minimal levels in some metropolitan areas. Housing subsidies in the form familiar to Dutch and German households are unknown.

In contrast, support levels for households in the Netherlands and West Germany, although reduced in recent years, are still significantly higher than in the United States. Thus, in addition to the substantial housing subsidies available in the Dutch housing market, there are equally important contributions to household welfare. Even with the booming economy of 2000, from a population of nearly 16 million people and 6.8 
million households, about 1.5 million persons were on welfare or social security (Note 3). Moreover, the Netherlands and West Germany have a system of generally available student grants. Although the grants are lower than the social minimum, they allow students to live away from the parents with limited parental help or with the income from a small part-time job.

German support levels are similar to those of the Netherlands. In West Germany, 3.3 percent (1993) of the population receive social welfare (Hilfe zum Lebensunterhalt). This proportion was much lower in 1980 (1.4 percent; Engstler 1997). Both in the Netherlands and in West Germany, social support (other than student grants) provides households with enough income to live independently from parental support.

\subsection{Three different geographies}

Although we are said to live in an increasingly globalized world, the majority of people still spend most of their life courses living in one single country. In that one country they complete their education, enter the housing market, and start their own independent household careers. The three countries under study are extremely different in size, population density, and in the extent to which regions differ in population density and availability of educational and job opportunities. The United States is on one extreme with its huge size and extreme differences between large metropolitan areas and vast rural areas, and the Netherlands is on the other with its size of only 35,000 square kilometres, its small number of cities with over 500,000 inhabitants, and its lack of rural areas at a remote distance from cities. West Germany is between these extremes.

\subsection{Spatial and temporal within-country contexts}

Within countries, the local availability of educational and job opportunities differs, and so does the necessity of leaving the parental home for reasons of education or work. The degree of urbanization forms an important indicator of the availability of opportunities. It also is a surrogate for the cost of housing: particularly in the United States, housing is much more costly in urban areas. Furthermore, degree of urbanization might also indicate differences in traditionality. In more urbanized areas, people tend to marry later and choose to cohabit more often (Manting 1994). In the United States, it is also important to distinguish between the larger regions. The South, for example, is known as somewhat more traditional than the rest of the country and marrying directly from the parental home is somewhat more common there (Mulder \& Clark 2000). 
It is also important to take account of temporal changes. Through time, the opportunity structure changes, and so does demographic behavior (see the above section on demographic change). Changes through time also include increases in real incomes and changing attitudes towards non-family living.

\subsection{Hypotheses on differences between the countries}

Our hypotheses on differences between the three countries focus on the degree of state support for housing market entry and on the geographical characteristics of the countries. Subsidies should, on the whole, increase the likelihood of leaving home, and decrease the importance of labor income and parental resources. We therefore expect to find the strongest influence of parental and individual resources in the United States, and the weakest in the Netherlands. We expect the different spatial structures to lead to a higher necessity to leave the parental home for work or education in the United States. Because of the large size of the country and the extreme urban-rural differences, we expect urban-rural differences to be of greater importance in the United States.

\section{Individual and parental resources}

Two major findings emerge from previous research into the role of individual and parental resources in leaving the parental home. First, resources, either of the parent or the child, are critical components which influence the likelihood of leaving home in various countries (Ermisch 1999; Mulder \& Clark 2000; Mulder \& Hooimeijer 2002; Murphy \& Wang 1998; Whittington \& Peters 1996). Not surprisingly, the amount of money a young adult has access to will influence the decisions to stay in the parental home or to leave and set up and independent household. Clearly, there will be considerable variation in the outcomes of the access to resources. A young adult may come from a wealthy background, but that household may not be willing to provide additional funds to make it possible to live independently, while another household will be willing to undertake that financial responsibility. A young adult with independent resources will tend to be willing to undertake living alone, and previous research documents this finding for the United States (Mulder \& Clark 2000). The young adults' resources were much more important than parental resources. The same research also showed that a young adult's resources are more pertinent to leaving home to live with a partner than to leaving home to live without a partner (Mulder \& Clark 2000).

The other finding is somewhat more controversial, but no less important. The so-

called feathered nest hypothesis describes a situation in which leaving home and union 
formation are delayed because it is more comfortable to stay in the family home (Goldscheider \& Goldscheider 1999). The existing literature provides only limited support for this hypothesis, but recent research has shown that young adults in the United States are indeed quite susceptible to the "comfort level" of their initial residence (Mulder \& Clark 2002). The importance of this finding is to reiterate the role of household resources in the likelihood and timing of leaving home.

Besides income, level of education is another major resource. After accounting for income, level of education indicates various phenomena. For the young adults, level of education indicates income potential. For the parents, it indicates the importance attached to their children's education. For both the parents and the young adults, it probably also indicates a degree of non-traditionality. Consequently, we expect higher education of both the parents and the young adults themselves to enhance the probability of leaving the parental home to live alone. For leaving home for union formation, it is less obvious what to expect: the aspect of income potential would lead to earlier union formation (compare Oppenheimer 1988) whereas the aspect of nontraditionality would lead to later union formation (compare Manting 1994).

For enrolment in education, we expect different effects on leaving the parental home to live with and without a partner. Theories stating that enrolment in education prevents people from forming partnerships and families have found ample empirical support (Blossfeld \& Huinink 1991; Oppenheimer 1988). Leaving the parental home to live without a partner may also be hampered by a lack of resources during the period of enrolment. At the same time, prolonged schooling leads to a greater necessity of attending colleges or universities far from the parental home, particularly in the United States.

\section{Data, methods and variables}

\subsection{Data}

Data are used from the Panel Study of Income Dynamics (PSID) for the United States, from two retrospective surveys for the Netherlands and the German Life History Study. In all data sets, the timing of leaving the parental home is measured as the year of the first residential transition out of the parents' home.

In choosing the data sets, we had to decide between maximum comparability and maximum data quality for each separate country. A choice for maximum comparability would have led us to use the PSID for the United States and the Socio-Economic Panels for the Netherlands and West Germany. However, the Socio-Economic panels have by far not run as long as the PSID and the opportunities for studying leaving the parental 
home are limited for the time being. Instead, we use data for the Netherlands and West Germany that are not completely comparable to the PSID, but have good quality.

The PSID is a panel data set of US families. The panel started in 1968. We use the 1975-93 waves, because information about educational enrolment, the completion of education, and the young adults' level of education is not reliable in the earlier waves. We selected the person-years of young adults aged 18-35 who either live in the parental home or are in their year of leaving home, either for residential independence or to start living in an educational institution. By including those leaving home for college, we use a different definition of leaving home from the one used in earlier work (Mulder \& Clark 2000; see also Whittington \& Peters 1996). The reason is that we think this inclusion makes the definition of leaving home more comparable with the definition used in the Dutch and German data (in which 'living in college' is not a separate category but counted as having left the parental home). The reason for starting the observation at age 18 is that transitions into residential independence under that age are not recorded in the PSID.

When the respondent leaves home for residential independence, the type of household after leaving is recorded (with or without a partner). For those respondents who leave home to live in an educational institution, however, there is no information about partnerships. We therefore have to assume that these respondents do not form partnerships at the moment they leave for college.

For the Netherlands and West Germany, we use data from retrospective surveys. From the respondents in these surveys, we use the information from age 18 up to leaving the parental home (or up to age 35 or the date of interview, if they do not experience this event).

The data for the Netherlands were taken from two retrospective life history studies: the SSCW survey (ESR/STP 1992) and the Netherlands Family Survey 1993 (NFS; Ultee \& Ganzeboom 1993). Both samples are representative of the Netherlands population aged 18 and over (SSCW) or 21 to 64 (NFS) in the beginning of the 1990s. The data from these two samples were pooled. The SSCW survey was conducted in 1993 among a sample of some 3,000 members in about 1,600 households. The Netherlands Family Survey was conducted in the period 1992-1993 among a sample of 1000 primary respondents (information was also gathered from the respondents' current partners; this information was not used for this paper). From these two data sets, those respondents were selected who were born between 1930 and 1969.

The German data were derived from the West German samples in the German Life History Study (GLHS). The GLHS consists of three studies, each representative of West Germans born in one or more three-year periods. Two of these are used for this paper. The first study was conducted in 1981-83 among 2171 respondents born 1929-31 1939-41 and 1949-51 (Mayer and Brückner 1989). The second study was conducted in 
1989 and comprised some 2000 members of birth cohorts 1954-56 and 1959-61 (Brückner and Mayer 1995). The six cohort groups will be referred to as the 19201930 194019501955 and 1960 cohorts.

\subsection{Methods}

We use logistic regression of person-years as a method for discrete-time event history analysis (Yamaguchi 1991). The dependent variable is the log-odds of the occurrence of a home-leaving event. We separately model two competing risks: the risk of leaving home to live with a partner, and the risk of leaving home to live without a partner (compare Buck \& Scott 1993; Mulder \& Clark 2000). In each of the models, the occurrence of the other event is treated as a censoring mechanism.

Because the data sets are not comparable enough to allow for pooling into one set, we had to analyse the three data sets separately. We also ran separate models for males and females.

The PSID data are household data. Within one parental family, the data of all eligible young adults are used. In the majority of families (70 percent), data of more than one respondent are used. Because the observations for respondents within families are not independent from each other, the standard assumptions for the calculation of standard errors are violated. The standard errors for the models based on PSID data were therefore corrected for the clustering of young adults within families (Hubercorrected standard errors; see Huber 1967).

\subsection{Independent variables}

Descriptive measures of the independent and dependent variables are in Table 1. Level of education and employment status were updated each year. So were the respondent's income, the degree of urbanization and the US region, but these were kept at the value the year before leaving home if a home-leaving event took place. For the United States, the father's level of education, the parents' income and the parents' tenure and house value were updated each year. For the Netherlands and West Germany, all variables for parental resources were measured for the respondent's age 15 . 
Table 1: $\quad$ Frequencies (means) of independent and dependent variables

\begin{tabular}{|c|c|c|c|c|c|c|}
\hline & \multicolumn{2}{|c|}{$\underline{\text { USA }}$} & \multicolumn{2}{|c|}{ Netherlands } & \multicolumn{2}{|c|}{ West Germany } \\
\hline & $\%$ (mean) & St dev & $\%$ (mean) & St dev & $\%$ (mean) & St dev \\
\hline Sex: Female ${ }^{a}$ & 47.8 & & 49.6 & & 48.0 & \\
\hline Education: Less than high school $/$ Primary ${ }^{\mathrm{c}, \mathrm{d}}$ & 26.9 & & 14.5 & & 66.2 & \\
\hline High school $/$ Lower secondary/lower vocational ${ }^{c, d}$ & 46.0 & & 42.9 & & 16.1 & \\
\hline Some college $\mathrm{e}^{\mathrm{b}} / \mathrm{Higher}$ secondary/middle vocational $\mathrm{l}^{\mathrm{c}, \mathrm{d}}$ & 21.1 & & 24.0 & & 5.3 & \\
\hline College degree $/$ /Higher vocational/ university ${ }^{c, d}$ & 5.9 & & 18.6 & & 12.4 & \\
\hline Daily activity: Working & 51.7 & & 56.7 & & 70.0 & \\
\hline In education & 24.7 & & 32.3 & & 7.9 & \\
\hline Other not working & 23.6 & & 11.0 & & 22.1 & \\
\hline Income $(\$ 1000 s)^{b} / I S E I^{c, d}$ & 6.65 & 12.9 & 4.47 & 1.5 & 4.29 & 1.3 \\
\hline Age group: $18-19$ & 34.2 & & 31.1 & & 31.6 & \\
\hline $20-21$ & 23.3 & & 25.2 & & 24.4 & \\
\hline $22-23$ & 15.7 & & 18.3 & & 16.6 & \\
\hline $24-25$ & 10.2 & & 11.1 & & 10.6 & \\
\hline $26-27$ & 6.3 & & 5.9 & & 6.5 & \\
\hline $28-30$ & 5.7 & & 4.6 & & 5.7 & \\
\hline $31-35$ & 4.6 & & 3.8 & & 4.5 & \\
\hline Father's education: Less than high school $/$ Lower $^{\mathrm{c}, d}$ & 48.7 & & 36.6 & & 75.7 & \\
\hline High school ${ }^{b} /$ Middle or higher $/$ Middle $^{d}$ & 29.1 & & 14.5 & & 7.8 & \\
\hline Some college ${ }^{b}$ & 11.9 & & & & 9.0 & \\
\hline College degree/Unknown ${ }^{\mathrm{c,d}}$ & 10.3 & & 48.9 & & 7.5 & \\
\hline City size: under $10,000^{b} /$ Urbanization: Countryside ${ }^{c, d}$ & 14.1 & & 21.0 & & 37.6 & \\
\hline $10,000-24,999^{b}$ Weakly urbanized ${ }^{c, d}$ & 9.7 & & 34.9 & & 20.9 & \\
\hline $25,000-49,999^{b} /$ Urbanized $^{c, d}$ & 7.7 & & 20.0 & & 15.1 & \\
\hline $50,000-99,999^{b} /$ Strongly urbanized ${ }^{c, d}$ & 11.3 & & 24.1 & & 26.4 & \\
\hline $100,000-499,999^{b}$ & 22.5 & & & & & \\
\hline$>=500,000^{\mathrm{b}}$ & 34.7 & & & & & \\
\hline US Region: Midwest & 22.8 & & & & & \\
\hline Northeast & 17.8 & & & & & \\
\hline South & 47.1 & & & & & \\
\hline West & 12.3 & & & & & \\
\hline Parents' income $(\$ 1000 \mathrm{~s})^{\mathrm{b}} /$ Father's ISEI $^{\mathrm{c}, \mathrm{d}}$ & 48.0 & 46.1 & 4.24 & 1.45 & 13.99 & 16.2 \\
\hline Father's ISEI missing: 1 & & & 15.2 & & 27.7 & \\
\hline Parents' housing tenure and house value: Rent & 32.2 & & & & 46.1 & \\
\hline Owner, house value lower $33 \%$ b $/ O w n^{d}$ & 31.2 & & & & 53.9 & \\
\hline Owner, house value middle $33 \%{ }^{\mathrm{b}}$ & 19.5 & & & & & \\
\hline Owner, house value upper $33 \%^{\mathrm{b}}$ & 17.1 & & & & & \\
\hline Birth cohort ${ }^{\mathrm{a}}: 1930-39^{\mathrm{c}} / 1930^{\mathrm{d}}$ & & & 17.1 & & 16.2 & \\
\hline $1940-49^{c} / 1940^{d}$ & & & 25.1 & & 17.8 & \\
\hline $1950-59^{c} / 1950^{d}$ & & & 33.5 & & 17.9 & \\
\hline $1955^{\mathrm{d}}$ & & & & & 24.1 & \\
\hline $1960-69^{c} / 1960^{d}$ & & & 24.3 & & 23.9 & \\
\hline Period: 1979-84 & 45.3 & & & & & \\
\hline $1985-89$ & 32.0 & & & & & \\
\hline $1990-93$ & 22.7 & & & & & \\
\hline Left parental home: Not (yet) & 82.7 & & 84.9 & & 86.4 & \\
\hline Alone & 12.2 & & 5.2 & & 6.0 & \\
\hline With partner & 5.1 & & 9.9 & & 7.6 & \\
\hline $\mathrm{N}$ person years & 19440 & & 15635 & & 22145 & \\
\hline $\mathrm{N}$ respondents & 5195 & & 2518 & & 3642 & \\
\hline
\end{tabular}

Percentages/means measured over person years;

${ }^{\text {a }}$ Percentages measured over respondents ${ }^{b}$ US, ${ }^{\mathrm{c}}$ The Netherlands, ${ }^{\mathrm{d}}$ West Germany 
Level of education was measured in four categories for all three countries. In each country, the lowest level indicates completion of primary education and the highest level indicates completion of university, college or higher vocational education. The two middle categories are somewhat less comparable because of the differences in the educational systems. 'Employment status' indicates whether the respondents are in paid work, in full-time education, or otherwise not working. Annual income is measured in 1000s of US dollars for the United States. For the Netherlands and West Germany we do not have direct income measures, but we have socio-economic status of the respondent's job measured according to the International Socio-Economic Index (Ganzeboom, De Graaf \& Treiman 1992). People with unknown socio-economic status are assigned the average status; a separate dummy indicates whether missing substitution has taken place. The respondent's age is measured in seven small categories to acknowledge the different age profiles of leaving home along the two different routes that may exist in the three countries.

The measurement of the father's education is similar to the respondent's, but for the Netherlands and West Germany we had to collapse some categories and add a category 'unknown' to account for the large number of missing values. Parental income and the father's socio-economic status are measured in the same way as those of the respondent.

Different measures were used for degree of urbanization. In the PSID, 'city size' stands for the number of inhabitants of the largest city or village in the respondent's county of residence. In the GLHS, respondents were asked to classify their place of residence as a house outside a village, a village, small town (up to 30,000 inhabitants), mid-size town $(30,000$ - 100,000 inhabitants $)$ or large city $(100,000$ or more inhabitants). In the Dutch data the municipalities where the respondents lived were coded according to degree of urbanization (measured as address density).

The temporal context is expressed in a period variable in the US data, and in cohort variables in the German and Dutch data. In the PSID, a period approach is most compatible with the annual observations of the panel of respondents. In the retrospective Dutch and German data, a cohort approach is a somewhat more obvious choice. More importantly, in the GLHS cohorts are spaced ten years apart, which makes a period approach less feasible because in each period different age groups are observed. 


\section{Analysis, models and results}

In all three countries, leaving the parental home is increasingly becoming separated from union formation. Over a few decades, the share of young adults leaving home to live without a partner has risen by several tens of percentage points (Figures 1 and 2). In the United States, this share is higher than in the Western European countries. In 1980, for example, it amounted to 70 percent for the United States, whereas it was just over 50 percent for the 1960 cohort in the Netherlands and West Germany. The models of leaving the parental home to form a union versus to live independently are in Table 2 for males and in Table 3 for females.

\subsection{Leaving home and the respondent's own resources}

In the United States, we find a consistently positive association between level of education and the likelihood of leaving the parental home either for union formation or to live without a partner. This result is found for both males (see Table 2) and females (see Table 3; see also Figure 3). For the Netherlands and West Germany, this positive association is only found for leaving home to live without a partner.

Figure 1: $\quad$ Percentage leaving without a partner in the USA by period

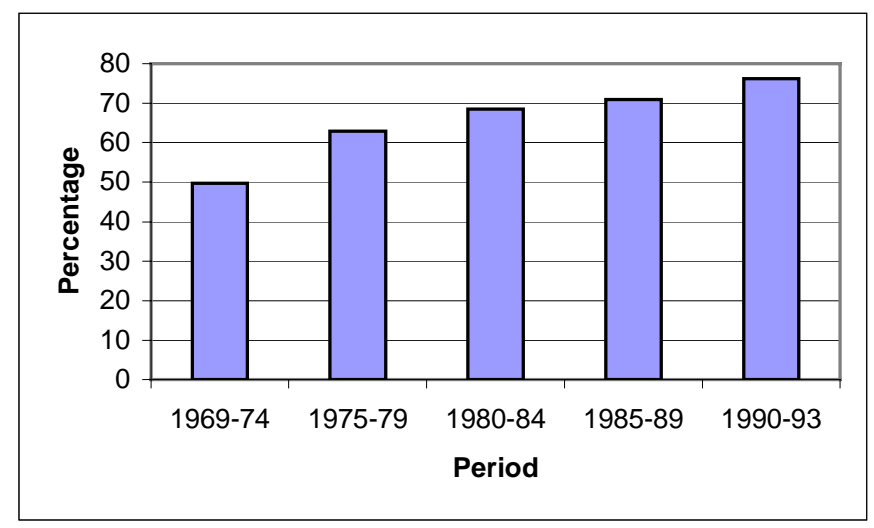


Figure 2: Percentage leaving without a partner in the Netherlands and WestGermany, by birth cohort

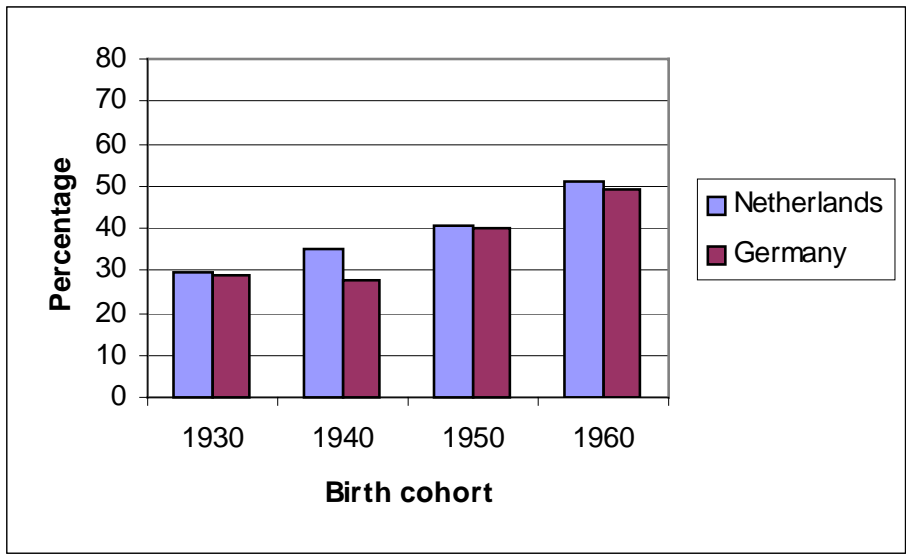

Figure 3: Annual probability of leaving without and with a partner in the USA, by level of education

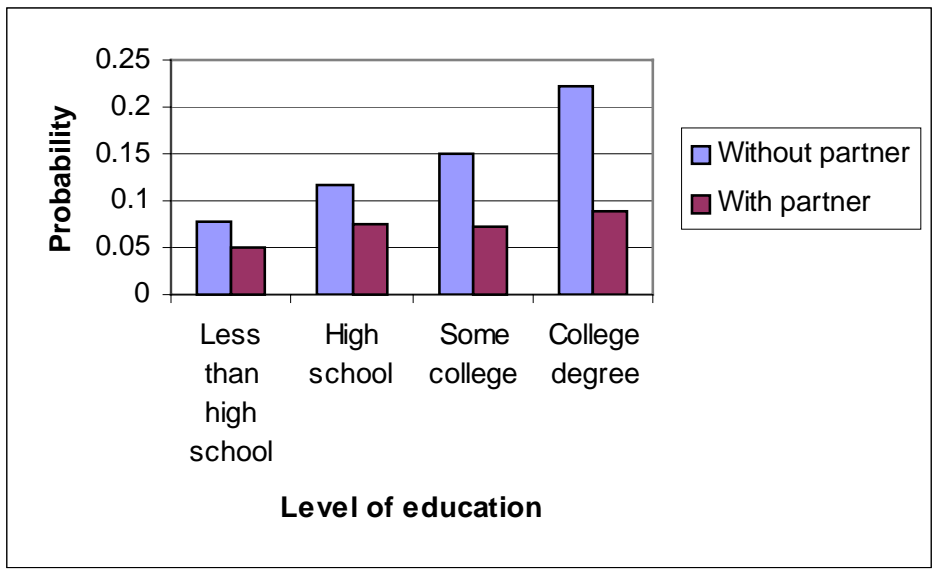


Figure 4: Annual probability of leaving without and with a partner in the Netherlands, by level of education

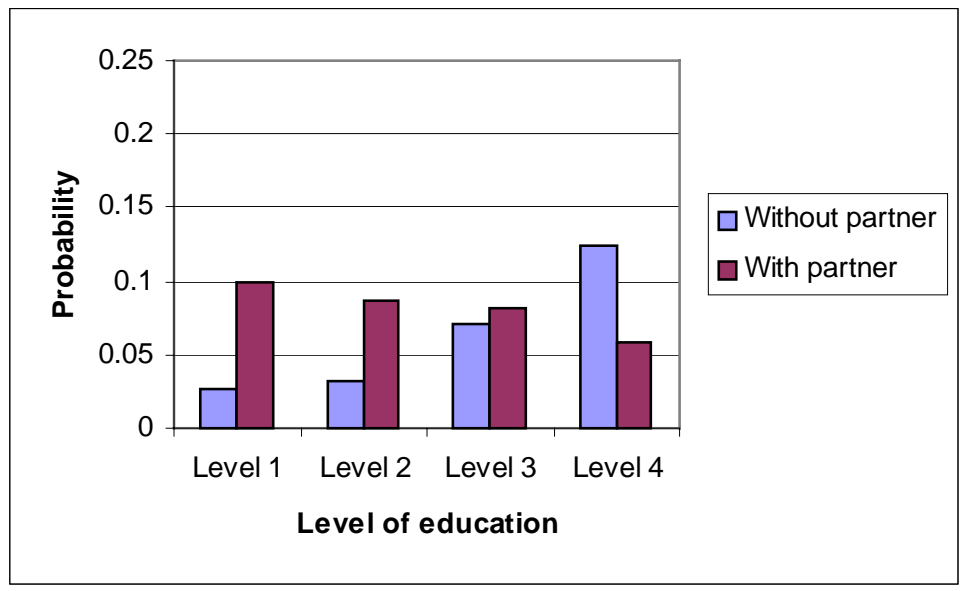

Figure 5: Annual probability of leaving without and with a partner in WestGermany, by level of education

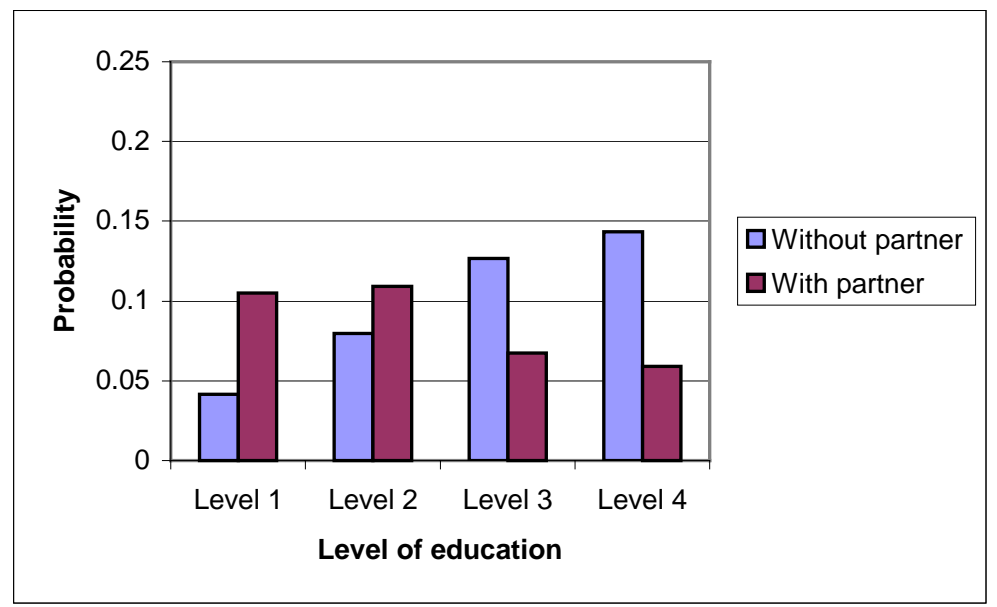


In the Netherlands, unlike in the United States, a higher level of education goes with a lower propensity to form a union from the parental home (see Table 2 and Figure 4). One gets the impression that, in the United States, schooling is mainly an asset creating earning potential and making young adults into attractive partners. In the Netherlands, this aspect of schooling seems to be less pertinent, and other aspects prevail - for example, the highly educated opt for flexibility and postpone commitments (Mulder \& Manting 1994). In West Germany, the influence of level of education resembles that in the Netherlands more than that in the United States (Table 2 and Figure 5). Like in the Netherlands, the impact of higher levels of education on union formation tends towards being negative, but only for tertiary education of females is it significant (Table 3).

The impact of employment status also shows interesting differences between the countries. In the United States, the effect of enrolment in education (versus being employed) differs markedly between union formation and leaving home to live independently. There is a strong negative effect on union formation, indicating an impact of lack of resources and/or incompatibility between student and family roles. There is a much smaller negative effect, and only for females, on leaving home to live without a partner. A considerable part of the young adults in the United States who go to college do so away from home (Mulder \& Clark 2002). It is in fact remarkable that, even though leaving home for college is so common in the United States, there is still a negative impact of enrolment in education on leaving home to live without a partner. Enrolment in education is positively associated with leaving home to live without a partner in the Netherlands. Leaving home during tertiary education is quite common in the Netherlands and, partly because of the student grant system, it happens not only among those who go to university far from home, but also among those who do so near home but prefer to be independent. The negative influence of educational enrolment on union formation is much more moderate in the Netherlands than in the United States, possibly indicating a smaller resource effect. In West Germany, the impact of enrolment in education is similar to the impact found for the United States, but it is less negative for union formation, and leaving to live without a partner is affected negatively just for males.

Non-employment for other than educational reasons ('other not working' in the tables) generally decreases the likelihood of both routes of leaving the parental home. Two consistent patterns are found: the effect is more negative for union formation than for independence, and it is more negative for males than for females. For the United States it is even positive for union formation by females. This finding is due to the fact that some women leave the labor market in their year of union formation, probably to become housewives. In an analysis in which we used a one-year-lagged version of this variable, the effect of non-employment was found to be negative. 
Table 2: $\quad$ Models of leaving the parental home in a year for males in US, the Netherlands and West Germany

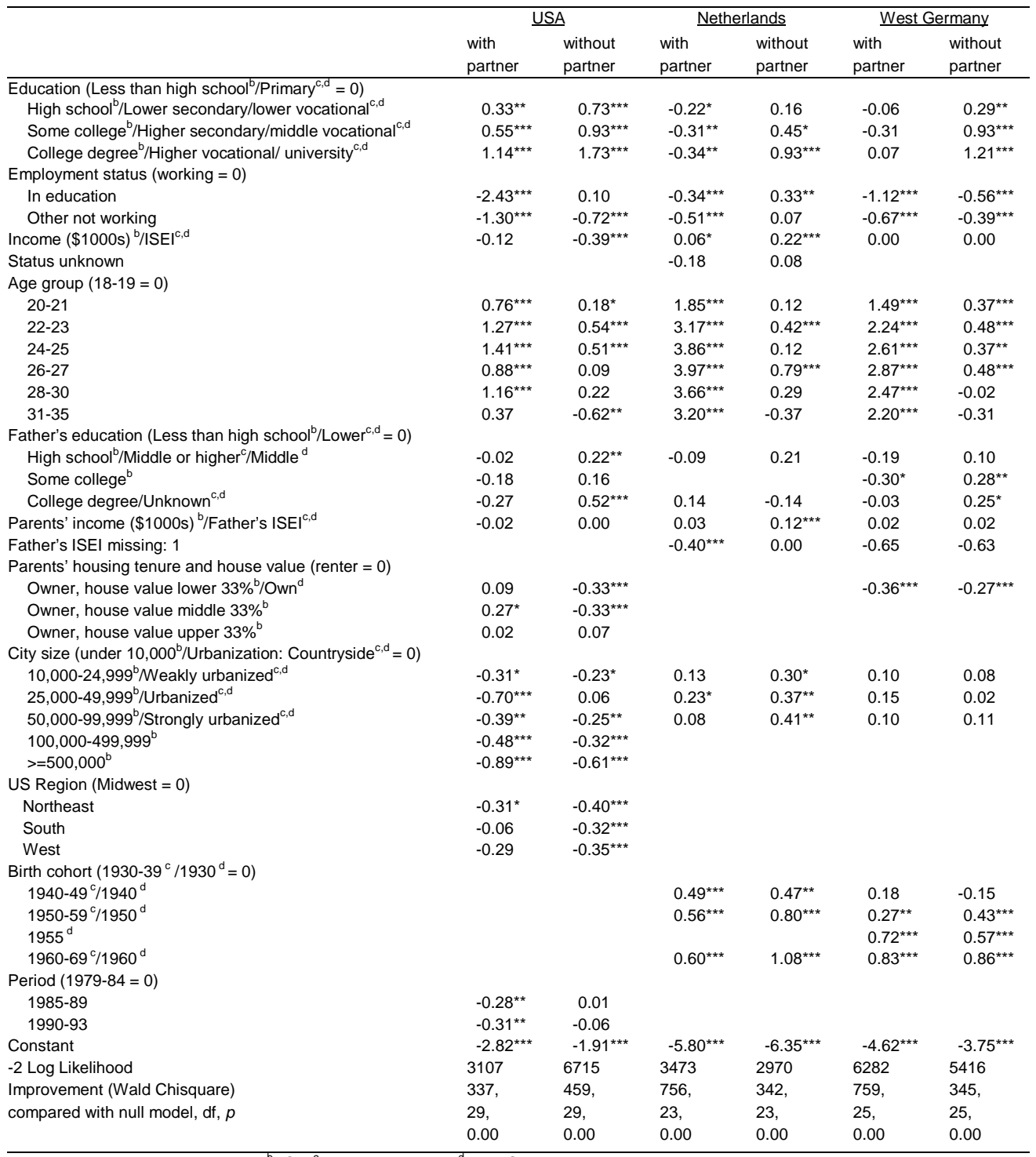

${ }^{\star} p<0.10 ;{ }^{\star \star} p<0.05 ;{ }^{\star \star \star} p<0.01 \quad{ }^{b}$ US, ${ }^{~}$ The Netherlands, ${ }^{d}$ West Germany 
Table 3: $\quad$ Models of leaving the parental home in a year for females in USA, the Netherlands and West Germany

\begin{tabular}{|c|c|c|c|c|c|c|}
\hline & \multicolumn{2}{|c|}{$\underline{\text { USA }}$} & \multicolumn{2}{|c|}{ Netherlands } & \multicolumn{2}{|c|}{ West Germany } \\
\hline & $\begin{array}{l}\text { with } \\
\text { partner }\end{array}$ & $\begin{array}{l}\text { without } \\
\text { partner }\end{array}$ & $\begin{array}{l}\text { with } \\
\text { partner }\end{array}$ & $\begin{array}{l}\text { without } \\
\text { partner }\end{array}$ & $\begin{array}{l}\text { with } \\
\text { partner }\end{array}$ & $\begin{array}{l}\text { without } \\
\text { partner }\end{array}$ \\
\hline \multicolumn{7}{|l|}{ Education (Less than high school $/$ Primary $^{\mathrm{c}, \mathrm{d}}=0$ ) } \\
\hline High school ${ }^{\mathrm{b}} /$ Lower secondary/lower vocational $^{\mathrm{c}, \mathrm{d}}$ & $0.62^{\star \star \star}$ & $0.52^{\star \star *}$ & $-0.22^{\star \star}$ & 0.15 & -0.02 & $0.57^{* \star *}$ \\
\hline Some college $\mathrm{e}^{\mathrm{b}} /$ Higher secondary/middle vocational ${ }^{\mathrm{c}, \mathrm{d}}$ & $1.00^{\star \star \star}$ & $0.34^{\star \star \star}$ & $-0.26^{*}$ & $0.71^{\star \star \star}$ & -0.19 & $0.91^{* \star *}$ \\
\hline College degree $/$ Higher vocational/ university ${ }^{\mathrm{c}, \mathrm{d}}$ & $1.27^{\star * *}$ & $0.87^{\star * \star}$ & $-0.53^{\star * *}$ & $1.12^{\star * *}$ & $-0.71^{* * *}$ & $1.19^{\star \star \star}$ \\
\hline \multicolumn{7}{|l|}{ Employment status (working $=0$ ) } \\
\hline In education & $-2.77^{\star \star *}$ & $-0.35^{\star \star \star}$ & $-0.63^{\star \star \star}$ & $0.29^{\star *}$ & $-0.59^{\star *}$ & 0.08 \\
\hline Other not working & $0.37^{\star \star \star}$ & $-0.22^{\star \star}$ & -0.08 & -0.20 & $-0.27^{\star * *}$ & $-0.23^{*}$ \\
\hline Income $(\$ 1000 \mathrm{~s})^{\mathrm{b}} / \mathrm{ISEI}^{\mathrm{c}, \mathrm{d}}$ & -0.16 & $-0.43^{\star \star \star}$ & $-0.06^{*}$ & 0.00 & $-0.05^{\star}$ & -0.04 \\
\hline Status unkown & & & 0.07 & $0.60^{\star *}$ & & \\
\hline \multicolumn{7}{|l|}{ Age group $(18-19=0)$} \\
\hline $20-21$ & -0.05 & 0.05 & $1.05^{\star \star \star}$ & 0.17 & $0.65^{\star \star \star}$ & $0.20^{*}$ \\
\hline $22-23$ & $0.26^{*}$ & $0.27^{\star \star}$ & $1.58^{\star \star \star}$ & 0.21 & $1.06^{* \star *}$ & -0.04 \\
\hline $24-25$ & 0.22 & $0.27^{\star \star}$ & $1.84^{\star \star \star}$ & $0.42^{*}$ & $1.08^{\star \star \star}$ & 0.23 \\
\hline $26-27$ & 0.06 & 0.06 & $1.66^{\star \star \star}$ & -0.38 & $0.97^{* \star *}$ & 0.23 \\
\hline $28-30$ & $-0.60^{* *}$ & -0.14 & $1.07^{\star \star \star}$ & -0.22 & $0.36^{*}$ & -0.34 \\
\hline $31-35$ & $-1.31^{\star \star *}$ & $-0.81^{\star * *}$ & 0.13 & 0.04 & 0.25 & $-1.31^{* *}$ \\
\hline \multicolumn{7}{|l|}{ Father's education (Less than high school ${ }^{b} /$ Lower $^{c, d}=0$ ) } \\
\hline High school ${ }^{b} /$ Middle or higher $/$ Middle $^{d}$ & $0.39^{\star \star \star}$ & 0.04 & -0.08 & $0.66^{\star \star \star}$ & -0.02 & 0.19 \\
\hline Some college $\mathrm{b}^{\mathrm{s}}$ & 0.23 & $0.28^{\star \star}$ & & & -0.05 & $0.41^{* *}$ \\
\hline College degree/Unknown ${ }^{c, d}$ & $0.36^{*}$ & $0.60^{\star \star \star}$ & -0.03 & 0.09 & 0.08 & $0.41^{* *}$ \\
\hline Parents' income $(\$ 1000 \mathrm{~s})^{\mathrm{b}} /$ Father's ISEI $^{\mathrm{c}, \mathrm{d}}$ & 0.01 & 0.00 & 0.01 & $0.08^{\star *}$ & -0.04 & 0.01 \\
\hline Father's ISEI missing: 1 & & & $-0.41^{* * *}$ & 0.19 & 1.50 & -0.40 \\
\hline \multicolumn{7}{|l|}{ Parents' housing tenure and house value $($ renter $=0$ ) } \\
\hline Owner, house value lower $33 \%$ o $/ O w^{d}$ & $0.39^{\star \star \star}$ & $-0.30^{\star \star *}$ & & & $-0.30^{\star \star *}$ & $-0.28^{\star \star \star}$ \\
\hline Owner, house value middle $33 \%{ }^{\mathrm{b}}$ & $0.60^{* * *}$ & -0.04 & & & & \\
\hline Owner, house value upper $33 \%{ }^{\mathrm{b}}$ & $0.62^{* \star *}$ & 0.04 & & & & \\
\hline \multicolumn{7}{|l|}{ City size (under $10,000^{b} /$ Urbanization: Countryside ${ }^{c, d}=0$ ) } \\
\hline $10,000-24,999^{b} /$ Weakly urbanized ${ }^{c, d}$ & 0.05 & -0.08 & 0.16 & 0.02 & $0.30^{\star * *}$ & 0.09 \\
\hline $25,000-49,999^{b} /$ Urbanized $^{c, d}$ & -0.14 & -0.08 & 0.18 & 0.16 & $0.25^{\star \star}$ & $0.26^{*}$ \\
\hline $50,000-99,999^{b} /$ Strongly urbanized ${ }^{c, d}$ & 0.06 & $-0.30^{* *}$ & 0.16 & $0.31^{*}$ & $0.23^{* *}$ & 0.19 \\
\hline $100,000-499,999^{b}$ & -0.25 & 0.02 & & & & \\
\hline$>=500,000^{\mathrm{b}}$ & $-0.91^{* * *}$ & $-0.31^{* * *}$ & & & & \\
\hline \multicolumn{7}{|l|}{ US Region (Midwest $=0$ ) } \\
\hline Northeast & 0.00 & $-0.23^{\star *}$ & & & & \\
\hline South & $0.30^{* *}$ & $-0.23^{* \star *}$ & & & & \\
\hline West & 0.30 & 0.02 & & & & \\
\hline \multicolumn{7}{|l|}{ Birth cohort $\left(1930-39^{c} / 1930^{d}=0\right)$} \\
\hline $1940-49^{c} / 1940^{d}$ & & & $0.57^{\star \star \star}$ & $0.66^{\star \star \star}$ & $0.31^{* \star *}$ & 0.26 \\
\hline $1950-59^{c} / 1950^{d}$ & & & $0.93^{\star \star *}$ & $0.89^{* * *}$ & $0.74^{* \star *}$ & $0.67^{\star * \star}$ \\
\hline $1955^{\mathrm{d}}$ & & & & & $1.17^{\star \star *}$ & 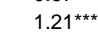 \\
\hline $1960-69^{\mathrm{c}} / 1960^{\mathrm{d}}$ & & & $0.98^{\star * *}$ & $0.98^{\star \star \star}$ & $1.03^{\star \star \star}$ & $1.24^{\star \star \star}$ \\
\hline \multicolumn{7}{|l|}{ Period $(1979-84=0)$} \\
\hline $1985-89$ & $-0.27^{\star \star}$ & -0.02 & & & & \\
\hline $1990-93$ & $-0.59^{\star * *}$ & -0.03 & & & & \\
\hline Constant & $-3.23^{\star \star *}$ & $-1.58^{\star \star *}$ & $-3.03^{\star \star \star}$ & $-4.78^{\star \star \star}$ & $-2.53^{\star \star *}$ & $-3.57^{* * *}$ \\
\hline-2 Log Likelihood & 3432 & 6331 & 3513 & 2574 & 6090 & 3679 \\
\hline Improvement (Wald Chisquare) & 308 & 205 & 406 & 259 & 404 & 418 \\
\hline compared with null model, $\mathrm{df}, p$ & 29 & 29 & 23 & 23 & 25 & 25 \\
\hline & 0.00 & 0.00 & 0.00 & 0.00 & 0.00 & 0.00 \\
\hline
\end{tabular}

${ }^{*} p<0.10 ;{ }^{* *} p<0.05 ;{ }^{* \star *} p<0.01{ }^{b}$ US, ${ }^{c}$ The Netherlands, ${ }^{d}$ West Germany 
Surprisingly, the respondent's own income is not significantly associated with leaving home for union formation in the United States, and the sign of the effect is not even positive. Apparently, the combination of education, employment status and age (which indicates the time the respondent has spent on the labor market, among other things) is more important to union formation of those still living at home than the actual amount of income earned in a year. For leaving home to live without a partner, the effect of income is significantly negative. This is mainly due to the fact that leaving home for college is included in the analysis. In an analysis in which leaving home for college was not included (not shown), the effect of income was still negative and significant, but it was much more moderate ( -0.03 for both males and females). It should be borne in mind that youth incomes are rather volatile. From previous work we know that, for the likelihood of leaving home, it does make a great deal of difference whether the young adult has an annual labor income exceeding \$5000 in 1993 dollars (Mulder \& Clark 2000). Because information about income is not available for the Netherlands and West Germany, we cannot use an indicator for the availability of a certain amount of income in this paper.

For the Netherlands and West Germany, we do not have information about income but about socio-economic status. In the Netherlands socio-economic status has a considerable impact on both routes of home-leaving, but only for males. In West Germany we find no significant impact of socio-economic status on leaving the parental home.

There is a strong age differentiation in leaving the parental home in all three countries. Several regularities can be found in the age patterns. The age differentiation is stronger for union formation than for independence; the peak particularly in union formation occurs at a younger age for males than for females; and the age curve is flattest for the United States, has a higher peak for West Germany, and the highest peak for the Netherlands.

\subsection{Leaving home and the parents' resources}

Leaving home is influenced by parental resources and human capital more generally, and this varies across the different countries in this study. For the United States, it shows responses which are more important to females than to males. High education of the father is associated with a greater likelihood of home-leaving, either with or without a partner, for females. For males, it only enhances the likelihood of leaving to live without a partner. No significant influence of parental income is found for the United States. But parental home-ownership is associated with a greater likelihood of forming a union, especially for females. This might indicate a positive influence of parental 
wealth on the parents' ability to help their children establish a household. In contrast, the effect of parental home-ownership on leaving to live without a partner is negative. As we argued elsewhere (Mulder \& Clark 2002; compare Goldscheider \& Goldscheider 1999), a comfortable parental home is also a 'feathered nest' from which leaving is less attractive.

Because of the more generous social security and student grant system, we had expected a smaller influence of parental resources on home-leaving in the Netherlands than in the United States. For union formation this is what we find, but we do not have information on parental home-ownership in the Netherlands. The negative effect of an unknown socio-economic status of the father is probably mostly a family structure effect (for example, the father was absent in the respondent's youth). Surprisingly, unlike in the United States, we not only find a positive impact of higher education of the father on leaving home to live without a partner, but also a positive impact of the father's socio-economic status. Even in a country where, in principle, social security and welfare are supposed to guarantee the opportunity of independent living to anyone over 18 years old, young adults apparently still use their parents' resources to speed up the process of gaining independence.

Two surprising findings for West Germany are the negative impact of high education of the father on union formation by males, and the negative effect of parental home-ownership on union formation by both males and females. Apparently, parental home-ownership has a different meaning in the United States and Germany. For one thing, home-ownership is more exclusive and more difficult to obtain in Germany. There is also a considerable amount of self-help construction of owner-occupied housing in Germany. A speculation could be, that children in part of the German homeowning families tend to aspire to become a homeowner immediately after leaving the parental home. The aspiration is sufficiently strong that they may postpone union formation until they have been able to become homeowners.

\subsection{Leaving home and the spatial-temporal context}

There is a striking difference between the three countries in the effect of degree of urbanization. In the United States, the likelihood of leaving home either with or without a partner is smaller when the largest city in the county is larger. Larger cities have less accessible housing markets. The countryside is somewhat more traditional, leading to earlier union formation. Furthermore, the large cities have more educational and job opportunities, so there is a smaller necessity of leaving home on one's own. In the Netherlands and West Germany, hardly any effect of degree of urbanization on union formation is found. The effect of urbanization on leaving home to live alone tends to be 
opposite to that in the United States in both European countries (although many of the parameters are not significant). Apparently, in the more populated European countries, young people are less inclined to leave home to cover a distance to work, and other rural-urban differences prevail. For example, cultural differences, or better opportunities to find some cheaper or shared form of accommodation in cities.

Because of the enormous size of the United States compared with the Netherlands and West Germany, we introduced a region variable into the models for the United States. We do find regional differences, but we refer to earlier work (Mulder \& Clark 2000) for a discussion.

Finally, in the period variable for the United States we see postponement of leaving the parental home to form a union, but no postponement of leaving to live without a partner. For the Netherlands and West Germany, we observe a longer period, and so the parameters for cohort change mainly reflect the acceleration of union formation over the late pre-war and early post-war cohorts. There has been some postponement of union formation in both countries, but apparently not enough to show up in these multivariate models. We also see acceleration in leaving home to live without a partner in the Netherlands and West Germany.

\section{Conclusions and findings}

In this paper we make a comparison between the United States and two Northwest European countries (the Netherlands and West Germany) with regard to the process of leaving the parental home to live with and without a partner. We expected to find differences between the United States and the European countries because of the differences in housing markets and welfare state systems. The extent to which the state supports housing demand and guarantees incomes is much greater in the European countries, and we expected this difference to have an impact on household formation and the extent to which individual resources matter. Between the two European countries, the differences are smaller, but the Netherlands is more generous in supporting the young and those in education.

Results from our investigation show that the greatest differences in trajectories of leaving home are indeed found between the United States on the one hand, and the Netherlands and West Germany on the other. Some of the differences do indeed suggest a greater importance of resources in the United States, but not all differences can be unambiguously attributed to the role of resources.

A major difference is that living without a partner is a much more common pathway out of the parental home in the United States than in the European countries. This is surprising from the point of view of the importance of resources, because one 
would think that establishing a household on one's own is more difficult to achieve without state support than living with a partner with whom resources can be pooled. An alternative explanation may be found in the completely different spatial layout of the United States. Because of the greater distances and the greater dispersion of educational and job opportunities, leaving home for college or labor market entry may be more necessary in the United States than in the Netherlands and West Germany.

Another major difference is found in the influence of education. In all three countries, enrolment in education has a negative impact on leaving home to live with a partner, but this influence is stronger in the United States. The impact of level of education on leaving the parental home to live without a partner is positive in all three countries. However, level of education is associated with a greater likelihood of union formation in the United States but a smaller one in the Netherlands and West Germany. Possibly, level of education is mainly a resource in the United States, but the cultural aspects of high education prevail in the two European countries.

Surprisingly, we find a non-significant impact of the young adult's income on leaving home to live with a partner for the United States, and a significantly negative impact on leaving home to live without a partner. We find only a moderate influence of parental resources. A crucial resource factor besides level of education, however, is employment status. Apparently, in the United States it does not matter so much how much a young adult earns but whether he or she has a job providing sufficient income to sustain a household of his or her own (compare Mulder \& Clark 2000). For West Germany, and particularly for the Netherlands, we find less impact of employment status. This finding indicates that, in the two Western European countries, the socialwelfare state system indeed allows an easier home-leaving process for those not in the labour force than does the US system in which market forces prevail. This difference, however, does not extend to other indicators of resources.

Spatially there are differences between the United States and the Netherlands and West Germany. Place is more important in the United States than in either the Netherlands or West Germany. It is likely that the sheer size of the United States influences leaving the parental home. Within the Netherlands, and even West Germany, it is possible to commute relatively long distances and maintain a local housing market. It may be that young adults in Europe are not willing to leave home, or more likely that the pattern of opportunities is such that they can access many jobs without major residential dislocation. Such behavior is not possible in the United States, and decisions to leave the parental home are clearly influenced by the pattern of educational and job opportunities. Earlier work on the effect of college attendance showed that young adults were likely to have different patterns of leaving home if they attended college away from home (Mulder \& Clark 2002). 
The study also shows that there are gender differences that cross cultural boundaries. In all three countries, we find indications that young women are more likely to be influenced by parents' resources than young men. The opposite is true for the young adult's own resources. No consistent gender difference in the influence of income is found, but enrolment in education and non-employment for other reasons is consistently more important to the household formation of males than to that of females.

The comparative research provides a new framework for considering questions about leaving home and the role of resources in general. It is clear from this analysis that the young adults' and the parents' resources are critically important in establishing an independent role in society and in the housing market in particular. At the same time there are very important differences across the geographical contexts that we have examined in this study. As we expected, the greater social support system in the Netherlands and in West Germany does have an impact and creates a greater social net for non-employed young adults leaving the nest. We should, however, not exaggerate the importance of the differences in timing and outcomes as a result of this support system.

\section{Acknowledgements}

Part of Clara Mulder's research was done while she was employed at the Urban Research centre Utrecht of Utrecht University. She thanks the geography department of the University of California, Los Angeles, for allowing her a research stay. Thanks are also due to Maarten van Ham for his help with the models with Huber-corrected standard errors. 


\section{Notes}

1. The restriction to the Western part of Germany is made because we extend our analyses to the period before 1989 when the political situation in East Germany was completely different from that in the West.

2. Housing payments are deductible against ordinary income, which is a significant advantage for homeowners.

3. Dutch systems ABW, WW, WAO 


\section{References}

Aassve, Arnstein, Francesco C. Billari, Stefano Mazzuco, and Fausta Ongaro. 2001. Leaving home ain't easy. A comparative longitudinal analysis of ECHP data. Rostock: Max Planck Institute for Demographic Research (MPIDR Working Paper WP 2001-038).

Billari, Francesco C., Dimiter Philipov, and Pau Baizan. 2001. Leaving home in Europe: The experience of cohorts born around 1960. Rostock: Max Planck Institute for Demographic Research (MPIDR Working Paper WP 2001-014).

Blossfeld, Hans-Peter and Johannes Huinink. 1991. "Human capital investments or norms of role transition? How women's schooling and career affect the process of family formation." American Journal of Sociology 97:143-168.

Bouvier, Leon F. and Carol J. De Vita. 1991. "The baby boom -- entering midlife." Population Bulletin 46:1-34.

Brückner, Hannah and Karl Ulrich Mayer. 1995. Lebensverläufe und gesellschaftlicher Wandel: Konzeption, Design und Methodik der Erhebung von Lebensverläufen der Geburtsjahrgänge 1954-1956 und 1959-1961. Berlin: Max-Planck-Institut für Bildungsforschung (Materialien aus der Bildungsforschung Nr. 48).

Buck, Nicholas and Jacqueline Scott. 1993. "She's leaving home: but why? An analysis of young people leaving the parental home." Journal of Marriage and the Family 55:863-874.

Cherlin, Andrew J., Eugenia Scabini, and Giovanna Rossi. 1997. "Still in the nest. Delayed home leaving in Europe and the United States." Journal of Family Issues 18:572-575.

Clark, William A.V. 2001. "The geography of immigrant poverty: selective evidence of an immigrant underclass." in Strangers at the Gates: New immigrants in Urban America., edited by R. W. Waldinger: University of California Press.

De Jong, Andries and Wim Van Hoorn. 1999. "Leaving home, and then?" Pp. 21-34 in Vital events. Past, present and future of the Dutch population, edited by J. Garssen, J. De Beer, L. Hoeksma, K. Prins, and R. Verhoef. Voorburg: Statistics Netherlands.

Engstler, H. 1997. Die Familie im Spiegel der amtlichen Statistik (The Family in the Mirror of Official Statistical Data). Bonn: Bundesministerium fur Familie, Senioren, Frauen und Jugend. 
Ermisch, John. 1999. "Prices, parents, and young people's household formation." Journal of Urban Economics 45:47-71.

Esping-Andersen, Goesta. 1999. Social foundations of postindustrial economies. Oxford: Oxford University Press.

ESR/STP. 1992. SSCW data file. Owner: Stichting Economische, Sociaal-culturele en Ruimtelijke Wetenschappen (ESR) of the Netherlands Organisation for the Advancement of Scientific Research (NWO), The Hague. Data collection: Stichting Telepanel, Amsterdam. Data management: Steinmetz Archive, Amsterdam (P1107).

Fernandez Cordón, Juan Antonio. 1997. "Youth residential independence and autonomy; a comparative study." Journal of Family Issues 18:576-607.

Ganzeboom, Harry B.G., Paul De Graaf, and Donald J. Treiman. 1992. "A standard international socio-economic index of occupational status." Social Science Research 21:1-56.

Goldscheider, Frances. 1997. "Recent changes in U.S. young adult living arrangements in comparative perspective." Journal of Family Issues 18:708-724.

Goldscheider, Frances and Calvin Goldscheider. 1999. The changing transition to adulthood. Leaving and returning home. Thousand Oaks, CA: Sage.

Haurin, Donald R., Patric H. Hendershott, and Susan Wachter. 1996. Expected home ownership and real wealth accumulation of youth. Cambridge, MA: National Bureau of Economic Research (Working Paper: 5629).

Hooimeijer, Pieter and Clara H. Mulder. 1998. "Changing ways of leaving the parental home: With a partner or alone." Pp. 137-151 in The joy of demography... and other disciplines, edited by A. Kuijsten, H. De Gans, and H. De Feijter. Amsterdam: Thela Thesis.

Huber, P.J. 1967. "The behavior of maximum likelihood estimates under nonstandard conditions." in Proceedings of the 5th Berkeley Symposium on Mathematical Statistics and Probability. Berkeley.

Manting, Dorien. 1994. Dynamics in marriage and cohabitation. An inter-temporal, life course analysis of first union formation and dissolution. Amsterdam: Thesis Publishers/PDOD.

Mayer, Karl Ulrich and Erika Brückner. 1989. Lebensverläufe und Wohlfahrtsentwicklung: Konzeption, Design und Methodik der Erhebung von Lebensverläufen der Geburtsjahrgänge 1954-1956 und 1959-1961. Berlin: Max- 
Planck-Institut für Bildungsforschung (Materialien aus der Bildungsforschung Nr. 35).

McClanahan, S. and L. Casper. 1995. "Growing diversity and inequality in the American Family." in State of the Union: American in the 1990s, edited by R. Farley: Russell Sage Foundation.

Mulder, Clara H. and Dorien Manting. 1994. "Strategies of nest-leavers: 'Settling down' versus flexibility." European Sociological Review 10:155-172.

Mulder, Clara H. and Michael Wagner. 1998. "First-time home-ownership in the family life course: a West German-Dutch comparison." Urban Studies 35:687-713.

Mulder, Clara H. and William A.V. Clark. 2000. "Leaving home and leaving the state: Evidence from the United States." International Journal of Population Geography 6:423-437.

—. 2002. "Leaving home for college and gaining independence." Environment and Planning A 34:981-999.

Mulder, Clara H. and Pieter Hooimeijer. 2002. "Leaving home in the Netherlands: Timing and first housing." Journal of Housing and the Built Environment 17:237-268.

Murphy, Mike and Duolao Wang. 1998. "Family and sociodemographic influences on patterns of leaving home in postwar Britain." Demography 35:293-305.

Oppenheimer, Valerie Kincade. 1988. "A theory of marriage timing." American Journal of Sociology 94:563-591.

Ultee, Wout C. and Harry B.G. Ganzeboom. 1993. Netherlands Family Survey 1992-93 [machine readable data set]. Codebook prepared by Harry B.G. Ganzeboom, Susanne Rijken, September 1993 edition. Changes and additions made by Harry B.G. Ganzeboom and Roland Weygold, January 1995 edition. Nijmegen, Netherlands: Dept. of Sociology, Nijmegen University.

Van de Kaa, D.J. 1987. "Europe's second demographic transition." Population Bulletin 42:1-57.

Whittington, Leslie and H.Elizabeth Peters. 1996. "Economic incentives for financial and residential independence." Demography 33:82-97.

Yamaguchi, Kazuo. 1991. Event history analysis. Newbury Park: Sage (Applied Social Research Methods Series 28). 